\title{
Topical Use of Cannabis sativa L. Biochemicals
}

\author{
Léonid Mnekin and Lionel Ripoll *
}

Laboratoire LASEVE, Département des Sciences Fondamentales, Université du Québec à Chicoutimi, 555 Boulevard de l'Université, Saguenay, QC G7H 2B1, Canada; lmnekin.pro@gmail.com

* Correspondence: Lionel_Ripoll@uqac.ca

Citation: Mnekin, L.; Ripoll, L.

Topical Use of Cannabis sativa L. Biochemicals. Cosmetics 2021, 8, 85 . https://doi.org/10.3390/ cosmetics 8030085

Academic Editors: Amparo Salvador Carreño and Juan Luis Benedé Veiga

Received: 25 August 2021

Accepted: 1 September 2021

Published: 8 September 2021

Publisher's Note: MDPI stays neutral with regard to jurisdictional claims in published maps and institutional affiliations.

Copyright: (c) 2021 by the authors. Licensee MDPI, Basel, Switzerland. This article is an open access article distributed under the terms and conditions of the Creative Commons Attribution (CC BY) license (https:// creativecommons.org/licenses/by/ $4.0 /)$.
Abstract: Cannabis sativa L. plant is currently attracting increasing interest in cosmetics and dermatology. In this review, the biologically active compounds of hemp are discussed. Particularly the complex interactions of cannabinoids with the endocannabinoid system of the skin to treat various conditions (such as acne, allergic contact dermatitis, melanoma, and psoriasis) with clinical data. Moreover, the properties of some cannabinoids make them candidates as cosmetic actives for certain skin types. Hemp seed oil and its minor bioactive compounds such as terpenes, flavonoids, carotenoids, and phytosterols are also discussed for their added value in cosmetic formulation.

Keywords: Cannabis sativa; cannabinoid; endocannabinoid topical; hemp seed oil

\section{Introduction}

It has already been 6000 years that humans use Cannabis as food, fiber, and medicine [1]. Nowadays, Cannabis has widely spread through the world [1]. It is a predominantly dioecious species, with only male flowers or female flowers [2]. This particularity opened the path to hybridization of the plant, and lead to thousands of cultivars [1]. There is a long taxonomic problem with the classification of the different strains [1]. It is generally accepted to divide the Cannabis sativa L. species into 3 subspecies: "Sativa" refers to strains with a limited amount of THC, "Indica" refers to strains producing principally THC, and "Ruderalis" refers to wild hemp strains [1].

The Cannabis sativa L. plant contains a diversity of bio-active compounds which are promising for topical application in dermatology [3] or as cosmetic ingredients [4,5]. Firstly, because of the high content of cannabinoids, which can modulate diverse inflammatory conditions and immune response via the endocannabinoid system [6]. Secondly, because of the Hemp Seed Oil, which has beneficial properties for the skin $[7,8]$. And thirdly, because of the diversity of minor bioactive active compounds such as terpenes, flavonoids, carotenoids, phytosterols [9-11].

Firstly, this review aims to gather knowledge about the various cannabinoids and their biological actions within and outside the endocannabinoid system. Secondly, to determine the added value of Hemp Seed Oil and its minor constituents compared to other oils for cosmetic formulations or dermatological use.

\section{Cannabis sativa L. Botany}

Cannabis sativa L. belongs to the Cannabaceae family. It is an annual herb [1]. The plant can reach a height higher than $5 \mathrm{~m}$ in the outdoor 6 months growing season, as shown in Figure 1a [12]. The leaves grow on opposite sides of the stem [13]. The leaves, stems, and bracts of the plants are covered by epidermal protuberances called trichomes [1]. There are two types of trichomes: glandular and non-glandular. The non-glandular trichomes are in the bracts, petioles, stipules, leaves, and stems and serve as a defense mechanism against abiotic and biotic stress. The glandular trichomes are responsible for the synthesis of cannabinoids, secondary metabolites, and terpenes in a viscous resin, as shown in Figure $1 b$ [14]. When the days start to shorten, the inflorescence is triggered and buds of 
flowers develop. Male plants die after the inflorescence while the females remain until winter [1].
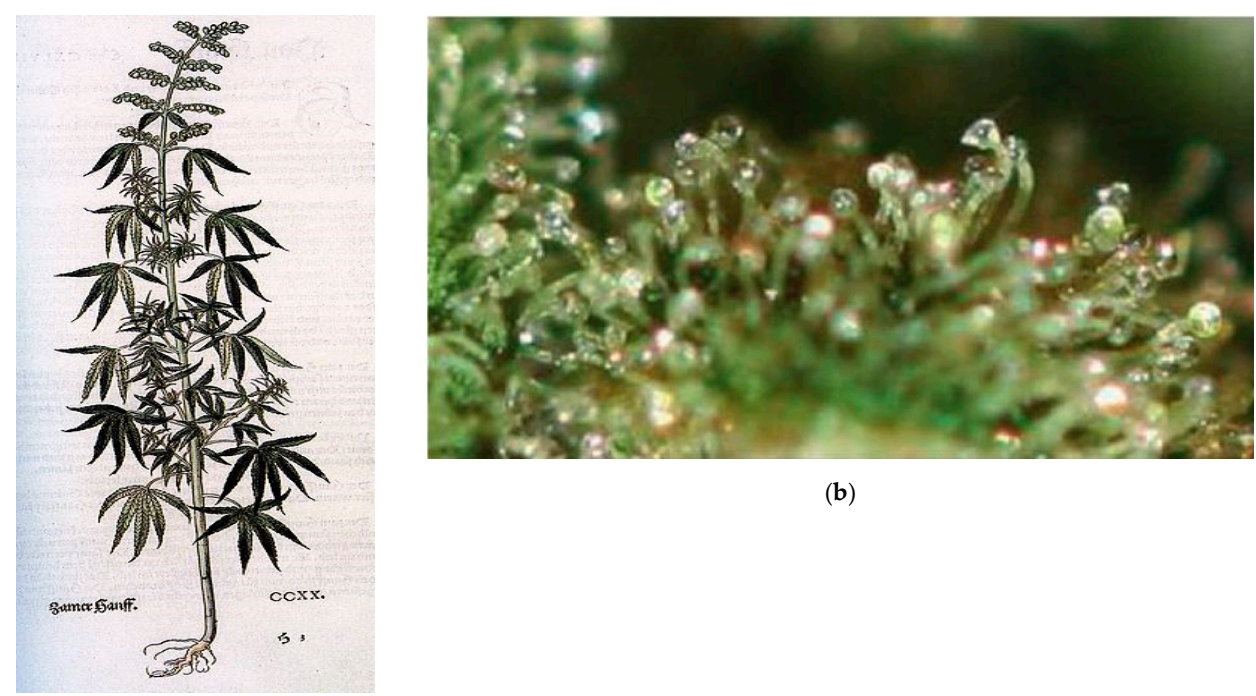

(b)

(a)

Figure 1. (a) Illustration of Cannabis sativa L. from Heinrich Füllmaurer, 1543 (b) Cannabis sativa L. glandular trichomes, photography by Ethan Budd Russo, reproduced by permission of Wiley-VHCA AG, Zurich, Switzerland [15].

\section{The Endocannabinoid System}

The endocannabinoid system (ECS), in the skin, is implied in cutaneous function such as cell differentiation modulation, growth and survival, inflammatory and immune responses, nociception, and hair growth. Indeed, dysregulation of the ECS seems to be involved in various skin disease conditions [16]. Two G protein-coupled receptors are involved in the ECS's regulation: cannabinoid type 1 receptor (CB1) and cannabinoid type 2 receptor (CB2) [17]. In the skin, CB1 is expressed in hair follicular cells, sensory neurons, immune cells, sebaceous glands, and keratinocytes while CB2 is expressed in sensory neurons, immune cells, sebaceous glands, and keratinocytes [18]. The CB1 main activity is the regulation of pain, of excessive neural activity and the extinction of evasive memories in the central nervous system [19]. It has been recently shown that CB1 regulate inflammatory response in various peripheral organs [20-22]. As for the skin, activation of CB1 downregulate the production of pro-inflammatory cytokine in keratinocytes, and protects the skin barrier [19]. Activation of CB2 has anti-inflammatory effects in skin; by inhibiting the macrophage 1 polarizations they downregulate pro-inflammatory cytokines [23]. The orphans G-coupled proteins receptors GPR 55 and GPR 18 can also be activated by some cannabinoids ligands [24-27]. Further studies are warranted to determine if GPR55 can be officially considered as a CB3 receptor or not. Depending on the target cell, GPR55 can have a pro-inflammatory or anti-inflammatory effects [27]. Nevertheless, its activation promotes human skin tumors and other squamous cell carcinomas [28]. GPR18 was revealed to have anti-inflammatory and anti-nociceptive activity in case of intestinal inflammation [29]. GPR18 is an active inhibitor of apoptosis in melanoma cells [30].

Two endogenous cannabinoids have been studied as the main natural ligands of the ECS, N-arachidonoylethanolamine (AEA), and 2-arachidonoylglycerol (2-AG [31]. AEA is synthesized by phospholipase D, 2-AG is synthesized by diacylglycerol lipase (DAGL), their degradation is mainly controlled by fatty acid amide hydrolase (FAAH), and monoacylglycerol lipase (MAGL) [32]. Palmitoylethanolamide (PEA) is also an endogenous ligand that binds with GPR55 but not with CB1 nor CB2, it has synergistic activity with AEA. PEA is synthesized by $N$-acyl-phosphatidyl-ethanolamine-selective phospholipase $\mathrm{D}$ and its degradation is mainly controlled by FAAH and $\mathrm{N}$-acylethanolamine-hydrolyzing 
acid amidase (NAAA) [33]. The MAGL, FAAH, and NAAA inhibition has an antipruritic effect [34-36].

\section{Secondary Cannabinoid Target}

Some of the cannabinoids ligands modulate greatly the response of the ECS by the activation of various transient receptor potential ion channels (TRPV1, TRPV2, TRPV3, TRPV4, TRPA1, and TRPM8) [18], of peroxisome proliferator-activated receptor alpha and gamma (PPAR $\alpha$; PPAR $\gamma$ ) transcription factors [16], and of serotonin receptors (particularly 5-HT1A, 5-HT2A, and 5-HT3 receptors) [37]. TRP ion channels permit the transit of various cations in the cells when activated by specific ligands [38]. PPAR enables, upon activation by specific ligands, the proliferation of peroxisomes which regulate inflammatory response and lipid metabolism [39].

The sum of these factors may result in synergistic or antagonistic biological effects. Therefore, it is important to take them into account to predict the pharmacological or cosmetic activity of a cannabinoid ligand. The biodynamic effect of these secondary cannabinoid targets and their location in the skin are detailed in Table 1 and illustrated in Figure 2.

Table 1. Location and biodynamic effects of main secondary targets of cannabinoid ligands.

\begin{tabular}{|c|c|c|c|}
\hline Type of Target & Name of Target & Cell & Biodynamic Effect upon Activation \\
\hline \multirow{6}{*}{$\begin{array}{l}\text { Transient potential } \\
\text { ion channel }\end{array}$} & TRPV1 [18,40-42] & $\begin{array}{l}\text { Sweat glands, Sebaceous glands, } \\
\text { Hair follicle, Keratinocytes, } \\
\text { Nerve ending, Fibroblasts, } \\
\text { Langerhans Cells }\end{array}$ & $\begin{array}{c}\text { Pro-inflammatory activity in cases of } \\
\text { psoriasis, atopic dermatitis [42], fungal } \\
\text { infection, burn wound, and UVB wound } \\
\text { Anti-inflammatory activity in case of allergic } \\
\text { contact dermatitis, barrier tissue infection, } \\
\text { and corneal wound }\end{array}$ \\
\hline & TRPV2 [18,41,43] & $\begin{array}{l}\text { Keratinocytes, Nerve ending, } \\
\text { Fibroblasts, Langerhans Cells }\end{array}$ & $\begin{array}{l}\text { Anti-inflammatory activity } \\
\text { Reduces chronic pain } \\
\text { Slows wound healing [43] }\end{array}$ \\
\hline & TRPV3 [18,41,44-46] & $\begin{array}{l}\text { Hair follicle, Keratinocytes, } \\
\text { Nerve ending, Fibroblasts, } \\
\text { Langerhans Cells }\end{array}$ & $\begin{array}{c}\text { Promotes epidermal differentiation and hair } \\
\text { growth [18]. } \\
\text { Pro-inflammatory activity in sebaceous } \\
\text { glands and epidermal keratinocytes [44]. } \\
\text { Pro-inflammatory activity in case of atopic } \\
\text { dermatitis [46]. }\end{array}$ \\
\hline & TRPV4 $[18,41,47,48]$ & $\begin{array}{l}\text { Keratinocytes, Nerve ending, } \\
\text { Fibroblasts, Langerhans Cells }\end{array}$ & $\begin{array}{c}\text { Repairs damaged skin } \\
\text { Downregulates lipid synthesis } \\
\text { Involved in the pathogenesis of } \\
\text { scleroderma [48] }\end{array}$ \\
\hline & TRPA1 $[18,41,49]$ & $\begin{array}{l}\text { Keratinocytes, Nerve ending, } \\
\text { Fibroblasts, Langerhans Cells }\end{array}$ & $\begin{array}{c}\text { Contributes to the pathogenesis of atopic } \\
\text { dermatitis and allergic contact dermatitis itch } \\
\text { Protective role against psoriasis }\end{array}$ \\
\hline & TRPM8 [18,41,50] & $\begin{array}{l}\text { Keratinocytes, Nerve ending, } \\
\text { Fibroblasts, Langerhans Cells }\end{array}$ & Anti-inflammatory activity \\
\hline \multirow{2}{*}{$\begin{array}{l}\text { Peroxisome } \\
\text { proliferator- } \\
\text { activated receptor } \\
\text { transcription faction }\end{array}$} & $\operatorname{PPAR} \alpha[51]$ & Keratinocytes, Langerhans Cells & $\begin{array}{c}\text { Anti-inflammatory activity via } \mathrm{NF} \kappa-B^{1} \\
\text { pathway }\end{array}$ \\
\hline & $\operatorname{PPAR} \gamma[52-55]$ & $\begin{array}{l}\text { Hair follicle, Keratinocytes, } \\
\text { Fibroblasts, Melanocytes }\end{array}$ & $\begin{array}{l}\text { Anti-inflammatory activity via } N F \mathcal{K}-B^{1} \\
\text { pathway [52] } \\
\text { Modulates potential of fibrotic skin disease } \\
\text { [53-55] }\end{array}$ \\
\hline \multirow{3}{*}{ Serotonin receptor } & 5-HT1A [56-60] & $\begin{array}{l}\text { Keratinocytes, Fibroblasts, } \\
\text { Melanocytes }\end{array}$ & $\begin{array}{c}\text { Promotes wound healing [59] } \\
\text { Anti-inflammatory activity in psoriatic skin } \\
{[56-58,60]}\end{array}$ \\
\hline & 5-HT2A $[56,57,60]$ & $\begin{array}{l}\text { Keratinocytes, Fibroblasts, } \\
\text { Nerve ending, Melanocytes }\end{array}$ & Pro-inflammatory activity in psoriatic skin \\
\hline & 5-HT3 [57] & Basal keratinocytes & Mediates the pruritus reaction \\
\hline
\end{tabular}

${ }^{1}$ Nuclear factor kappa-B. 


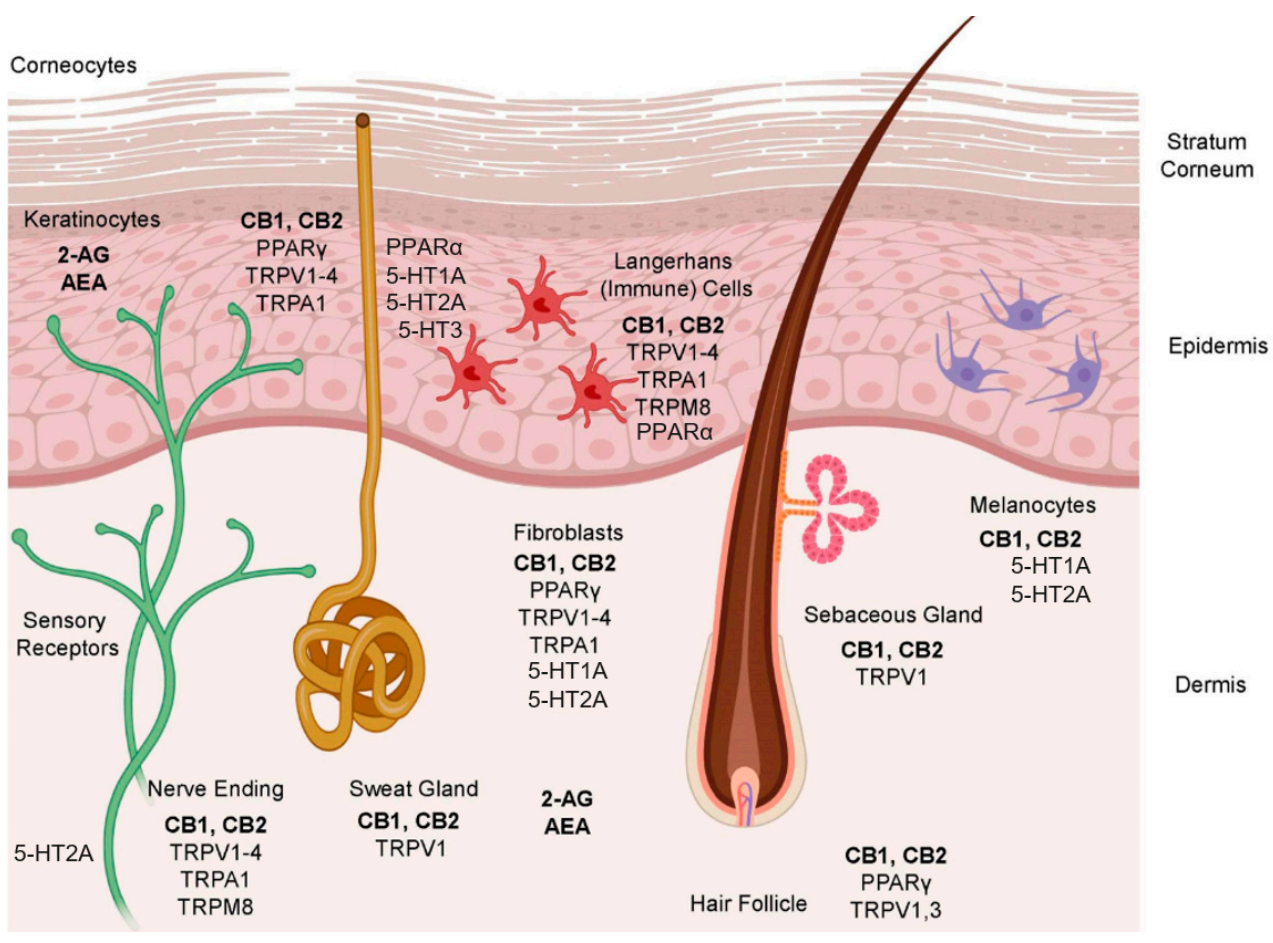

Figure 2. The repartition of CB1 and CB2, the TRPV1-4 channels, the TRPM8 channel, the PPARs transcription factors, and serotonin 5-HT1A, 5-HT2A, 5-HT3 receptors in skin cells, modificated with the permission of Dove Medical Press, Macclesfield, United Kingdom [61].

\section{Cannabinoids}

The cannabinoids, which are synthesized in the glandular trichomes [2] of Cannabis sativa L. are exogenous ligands of the ECS [62]. Therefore, they can interact with endocannabinoid receptors and some of the channels and receptors described below [62].

To date, almost 200 cannabinoids have been identified, and a vast majority of them are from Cannabis sativa L. [63]. They are divided into 11 classes: Delta-9 Tetrahydrocannabinol $(\triangle 9-\mathrm{THC})$ type, Cannabigerol (CBG) type, Cannabinol (CBN) type, Cannabichromene (CBC) type, Cannabitriol (CBT) type, Cannabidiol (CBD) type, Delta-8 Tetrahydrocannabinol $(\triangle 8$-THC) type, Cannabielsoin (CBE) type, Cannabicyclol (CBL) type, Cannabinodiol (CBND) type, and miscellaneous type.

The biosynthesis of all these cannabinoids (see Figure 3) originates from Cannabigerolic Acid (CBGA) products by Geranyl Pyrophosphate (GPP) and Olivetolic Acid (OA) or Divarinic Acid (DA), catalyzed by the Cannabigerolic Acid Synthase (CBGAS) enzyme.

Delta-9 Tetrahydrocannabinol $(\triangle 9-\mathrm{THC})$ is the principal cannabinoid from Cannabis sativa L. Cannabidiol (CBD) is the most abundant non-psychoactive cannabinoid derived from Cannabis sativa L. [1]. $\triangle 9$-THC, $\triangle 9$-THCA, $\triangle 9$-THCV, $\triangle 9$-THCVA, CBD, CBDA, CBDV, CBG, CBGA, CBGV, CBC, and CBN have been studied regarding their interaction with the ECS and the secondary cannabinoids targets. The data regarding these interactions is available in Table 2. 


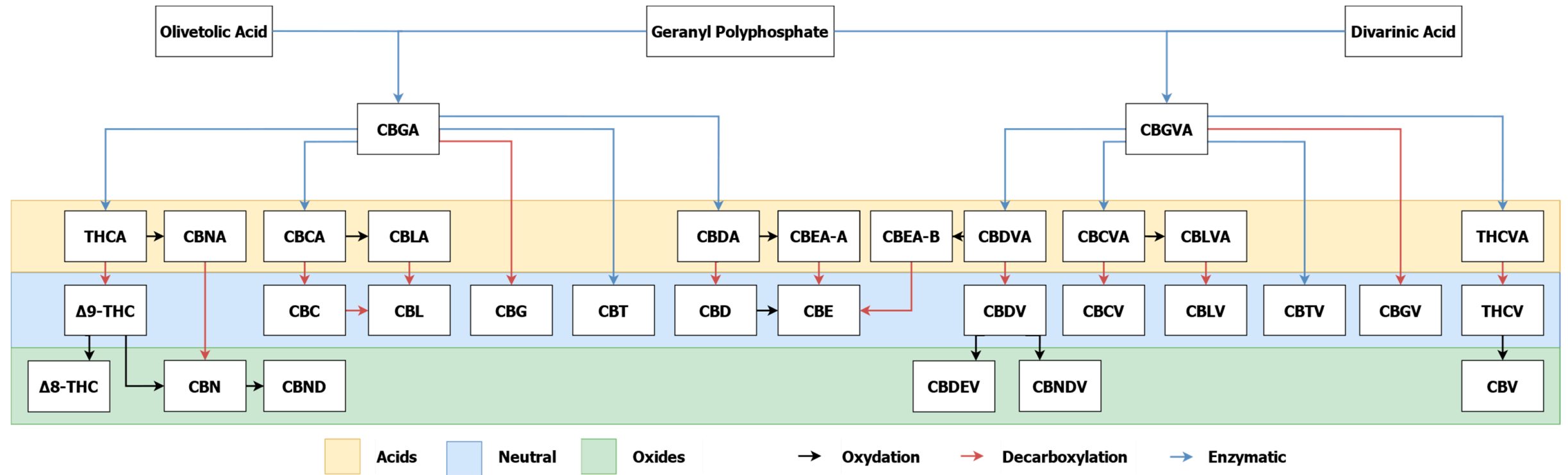

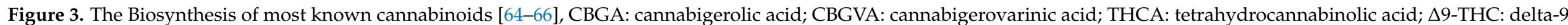

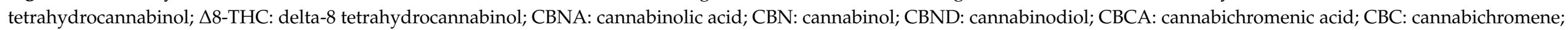

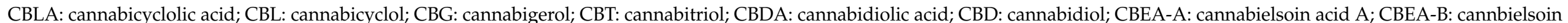

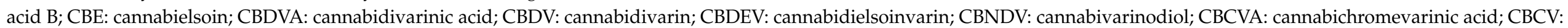

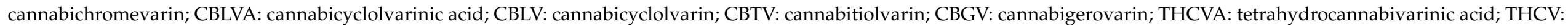
tetrahydrocannabivarin; CBV: cannabivarin. 
Table 2. Biodynamic effects of 12 cannabinoids.

\begin{tabular}{|c|c|c|c|c|c|c|c|c|c|c|c|c|}
\hline Cannabinoid & $\Delta 9$-THC & $\triangle 9-\mathrm{THCV}$ & $\triangle 9$-THCA & $\triangle 9$-THCVA & CBD & CBDA & CBDV & CBG & CBGA & CBGV & СВС & CBN \\
\hline CB1 & $\mathrm{PAG}^{1}[67]$ & $\mathrm{AN}^{3}[68]$ & $\mathrm{AG}^{2}$ [69] & & $\begin{array}{c}\mathrm{NCAG}^{4} \\
{[70,71]}\end{array}$ & $\mathrm{wAG}^{2,6}[72]$ & $/{ }^{9}[72]$ & $\mathrm{wAG}^{2,6}[73]$ & $/{ }^{9}[74]$ & $\operatorname{IAG}^{5}[74]$ & $/{ }^{9}[75]$ & $\operatorname{PAG}^{1}[76]$ \\
\hline CB2 & PAG $^{1}$ [67] & $\mathrm{PAG}^{1}[68]$ & IAG $^{5}[69]$ & & $\operatorname{IAG}^{5}[70,71]$ & $\mathrm{wAG}^{2,6}[68]$ & $\mathrm{AG}^{2}[68,74]$ & $\begin{array}{c}\text { wPAG } 1,6 \\
{[72,73]}\end{array}$ & $/{ }^{9}[74]$ & $\operatorname{IAG}^{5}[74]$ & $\mathrm{AG}^{2}[75]$ & $\mathrm{PAG}^{1}[76]$ \\
\hline GPR18 & $\mathrm{AG}^{2}$ [77] & & & & $\mathrm{AN}^{3}[77]$ & & & & & & & $\mathrm{AG}^{2}[78]$ \\
\hline GPR55 [79,80] & $\mathrm{AN}^{3}[28]$ & $\mathrm{wAG}^{2,6}[79]$ & $\mathrm{wAG}^{2,6}[79]$ & & $\begin{array}{c}\text { wAN }^{3,6} \\
{[79,80]}\end{array}$ & $\mathrm{wAN}^{3,6}[79]$ & $\operatorname{PoAN}^{3,7}[79]$ & $\mathrm{AN}^{3}[79]$ & PoAN $3,7[79]$ & PoAN $3,7[79]$ & & $\mathrm{AN}^{3}[78]$ \\
\hline TRPV1 [81] & $\mathrm{wAG}^{2,6}$ & PoAG 2,7 & $\mathrm{wAG}^{2,6}$ & $\mathrm{wAG}^{2,6}$ & PoAG 2,7 & $\mathrm{wAG}^{2,6}$ & $\mathrm{wAG}^{2,6}$ & $\mathrm{AG}^{2}$ & $\operatorname{PoAG}^{2,7}$ & PoAG 2,7 & $\mathrm{wAG}^{2,6}$ & $\mathrm{wAG}^{2,6}$ \\
\hline TRPV3 [82] & $\mathrm{wAG}^{2,6}$ & PoAG 2,7 & $\mathrm{wAG}^{2,6}$ & $\mathrm{wAG}^{2,6}$ & $\mathrm{AG}^{2}$ & $\mathrm{wAG}^{2,6}$ & $\mathrm{wAG}^{2,6}$ & $\mathrm{wAG}^{2,6}$ & $\mathrm{wAG}^{2,6}$ & $\mathrm{wAG}^{2,6}$ & $\mathrm{wAG}^{2,6}$ & $\mathrm{wAG}^{2,6}$ \\
\hline TRPV4 [82] & $\mathrm{wAG}^{2,6}$ & PoAG 2,7 & $\mathrm{wAG}^{2,6}$ & $\mathrm{wAG}^{2,6}$ & $\mathrm{wAG}^{2,6}$ & $\mathrm{wAG}^{2,6}$ & $\mathrm{AG}^{2}$ & $\mathrm{wAG}^{2,6}$ & $\mathrm{AG}^{2}$ & $\mathrm{wAG}^{2,6}$ & $\mathrm{wAG}^{2,6}$ & $\mathrm{wAG}^{2,6}$ \\
\hline TRPA1 [81] & $\mathrm{AG}^{2}$ & $\mathrm{wAG} 2,6$ & $\mathrm{wAG} 2,6$ & $\mathrm{wAG}^{2,6}$ & PoAG 2,7 & $\mathrm{AG}^{2}$ & $\mathrm{AG}^{2}$ & $\mathrm{AG}^{2}$ & $\mathrm{wAG}^{2,6}$ & $\mathrm{AG}^{2}$ & PoAG 2,7 & $\mathrm{PoAG}^{2,7}$ \\
\hline TRPM8 [81] & PoAN 3,7 & $\mathrm{AN}^{3}$ & PoAN 3,7 & $\mathrm{AN}^{3}$ & PoAN 3,7 & $\mathrm{AN}^{3}$ & $\mathrm{AN}^{3}$ & $\mathrm{AN}^{3}$ & $\mathrm{AN}^{3}$ & $\mathrm{AN}^{3}$ & $\mathrm{AG}^{2}$ & PoAN 3,7 \\
\hline PPAR $\alpha$ & $\mathrm{AG}^{2}$ [83] & & $/{ }^{9}[84]$ & & $/{ }^{9}[85]$ & $\operatorname{PAG}^{1}[85]$ & & PAG $^{1}$ [85] & $\mathrm{AG}^{2}$ [85] & & & \\
\hline $\operatorname{PPAR} \gamma[83,85]$ & $\mathrm{AG}^{2}[83,86]$ & $/{ }^{9}[83]$ & $\operatorname{PAG}^{1}[69,83]$ & & $\mathrm{AG}^{2}[86,87]$ & $\operatorname{PAG}^{1}[85,88]$ & & $\operatorname{PAG}^{1}[73,85]$ & $\mathrm{PAG}^{1}[85]$ & & $\mathrm{wAG}^{2,6}[86]$ & \\
\hline 5-HT1A & $/{ }^{9}[89]$ & $\mathrm{AG}^{2}$ [90] & & & $\mathrm{AG}^{2}$ [76] & $\mathrm{AG}^{2}$ [91-93] & & $\operatorname{PoAN}^{3,7}[73]$ & & & & \\
\hline MAGL [81] & & $\mathrm{IN}^{8}$ & PoIN 7,8 & $\mathrm{IN}^{8}$ & 19 & $\mathrm{IN}^{8}$ & 19 & PoIN 7,8 & $\mathrm{IN}^{8}$ & $\mathrm{wIN}^{6,8}$ & PoIN $^{8}$ & PoIN $^{8}$ \\
\hline NAAA [81] & & wIN $^{6,8}$ & $\mathrm{IN}^{8}$ & $\mathrm{wIN}^{6,8}$ & $\mathrm{IN}^{8}$ & PoIN 7,8 & $\mathrm{IN}^{8}$ & $\mathrm{wIN}^{6,8}$ & PoIN 7,8 & PoIN $^{7,8}$ & $\mathrm{IN}^{8}$ & $\mathrm{IN}^{8}$ \\
\hline FAAH [81] & & $\mathrm{wIN}^{6,8}$ & PoIN 7,8 & wIN $^{6,8}$ & PoIN 7,8 & PoIN 7,8 & $\mathrm{IN}^{8}$ & $\mathrm{IN}^{8}$ & PoIN 7,8 & PoIN 7,8 & $\mathrm{IN}^{8}$ & $\mathrm{IN}^{8}$ \\
\hline
\end{tabular}

${ }^{1}$ Partial agonist; ${ }^{2}$ Agonist; ${ }^{3}$ Antagonist; ${ }^{4}$ Non-competitive agonist; ${ }^{5}$ Inverse agonist; ${ }^{6}$ weak; ${ }^{7}$ Potent; ${ }^{8}$ Inhibitor; ${ }^{9}$ No activation. 
Moreover, some cannabinoids have specific particularities regarding their biodynamic activity regarding the skin.

CBD and CBG are transcriptional repressors that can control cell differentiation and proliferation in the skin [96]. CBD induces nuclear export and degradation of BACH1, reducing stress oxidation and skin aging [61,97]. CBG is an agonist of $\alpha 2$-adrenoceptor [73,98], it inhibits the endocannabinoid membrane transporter [50,79,82]. CBC is the most potent agonist of the TRPA1 channel $[81,82,99]$. CBDV is a partial agonist of dopamine D2-like receptors [100]. It has been shown recently that D2-like receptor agonism in the skin, promotes the recovery of the skin barrier and wound healing [101-103].

Some of these phytocannabinoids (mainly THC and CBD) have been tested as a treatment against various skin conditions (see Table 3).

Table 3. Clinical evidence of the therapeutical potential of various cannabinoids.

\begin{tabular}{|c|c|c|c|c|}
\hline Disease & Phytocannabinoid & Model & Outcome & Reference \\
\hline \multirow{4}{*}{ Acne } & THC and CBD & In vivo (mouse) & $\begin{array}{c}\text { Inhibition of cyclooxygenase and } \\
\text { lipoxygenase }\end{array}$ & [104] \\
\hline & CBD & $\begin{array}{l}\text { In vitro (human } \\
\text { sebocytes) }\end{array}$ & $\begin{array}{l}\text { Inhibition of pro-inflammatory p65 NF-kB } \\
1 \text { pathway }\end{array}$ & [70] \\
\hline & $\begin{array}{c}\text { THCV } \\
\text { CBC, CBDV } \\
\text { CBG, CBGV }\end{array}$ & $\begin{array}{l}\text { In vitro (human } \\
\text { sebocytes) }\end{array}$ & $\begin{array}{l}\text { THCV suppresses sebocytes proliferation, } \\
\text { arachidonic acid-induced seborrhoea } \\
\text { lipogenesis, and has a strong } \\
\text { anti-inflammatory action. } \\
\text { CBC, CBDV suppresses arachidonic } \\
\text { acid-induced seborrhoea lipogenesis. } \\
\text { CBG and CBGV increase the sebaceous } \\
\text { lipid production (pro-lipogenic and } \\
\text { pro-acne effect). }\end{array}$ & [105] \\
\hline & BTX 1503 (CBD) & $\begin{array}{l}\text { Phase } 2 \text { successfully } \\
\text { ended ( } 5 \text { dose groups, } \\
368 \text { subjects) }\end{array}$ & $40 \%$ reduction of lesions after 12 weeks & [106] \\
\hline \multirow{3}{*}{$\begin{array}{l}\text { Allergic Contact } \\
\text { Dermatitis }\end{array}$} & CBD & In vitro (HaCaT cells) & $\begin{array}{l}\text { Suppresses inflammatory reaction by the } \\
\text { inhibition of MCP2 }{ }^{2}, \mathrm{IL}-6^{3}, \mathrm{IL}-8^{3} \text {, and } \\
\text { TNF- } \alpha^{4}\end{array}$ & [107] \\
\hline & CBD & In vitro (Splenocytes) & $\begin{array}{l}\text { Suppresses inflammatory reaction by the } \\
\text { inhibition of IL- } 6^{3}, \mathrm{IL}-8^{3}, \mathrm{IL}-17^{3} \\
\text { TNF- } \alpha^{4} \text {, and IFN- } \gamma^{5} \text {. } \\
\text { Inhibition of T-cells and B-cells mediated } \\
\text { response }\end{array}$ & [108] \\
\hline & THC & $\begin{array}{l}\text { In vivo (CBR-deficient } \\
\text { mouse) }\end{array}$ & $\begin{array}{c}\text { Suppresses inflammatory reaction by the } \\
\text { inhibition of IFN- } \gamma^{5}, \mathrm{MCP} 1^{2}, \mathrm{MCP} 2^{2} \text {, } \\
\text { and IP- } 10^{6} \text {. }\end{array}$ & [109] \\
\hline Kaposi Sarcoma & CBD & $\begin{array}{l}\text { In vitro (infected } \\
\text { endothelial cells) }\end{array}$ & $\begin{array}{l}\text { Induction of apoptosis by the reduction of } \\
\text { GRO- } \alpha^{7} \text {, the inhibition of vGPCR }{ }^{8} \text {, and } \\
\text { by the reduction of VEGF-C }{ }^{9} \text { and } \\
\text { VEGFR-3 }{ }^{10}\end{array}$ & [110] \\
\hline \multirow[t]{3}{*}{ Melanoma } & $\begin{array}{c}\text { THC } \\
\text { THC and CBD (Sativex) }\end{array}$ & $\begin{array}{l}\text { In vitro (melanoma } \\
\text { cells) and in vivo } \\
\text { (mouse) }\end{array}$ & $\begin{array}{l}\text { Reduction in tumor size with THC+CBD } \\
\text { more effective than THC alone }\end{array}$ & [111] \\
\hline & $\mathrm{THC}$ & In vivo (mouse) & Inhibition of melanoma growth & [112] \\
\hline & CBD & In vivo (mouse) & Reduction in tumor size & [113] \\
\hline \multirow[t]{2}{*}{ Psoriasis } & THC and CBD & $\begin{array}{l}\text { In vitro (human-skin } \\
\text { keratinocytes) }\end{array}$ & Inhibition of keratinocytes proliferation & [114] \\
\hline & $\mathrm{CBD}$ and $\mathrm{CBG}$ & $\begin{array}{l}\text { Human trial } \\
\text { (2 subjects) }\end{array}$ & $16-33 \%$ reduction of lesions after 6 weeks & [115] \\
\hline
\end{tabular}

${ }^{1}$ Nuclear factor kappa-B; ${ }^{2}$ Monocyte chemotactic protein; ${ }^{3}$ Interleukin; ${ }^{4}$ Tumor necrosis factor alpha; ${ }^{5}$ Interferon gamma; ${ }^{6}$ interferon gamma-induced protein $10 ;{ }^{7}$ Growth-regulated oncogene alpha; ${ }^{8}$ v G-protein coupled receptor; ${ }^{9}$ Vascular endothelial growth factor C; ${ }^{10}$ Vascular endothelial growth receptor 3. 
Cannabinoids exhibit frequently antioxidant, antimicrobial activity, and less frequently a photoprotectant (see Table 4).

Table 4. Antioxidant, antibacterial and photoprotectant activity of various phytocannabinoids.

\begin{tabular}{|c|c|c|c|c|c|c|c|c|c|c|c|c|}
\hline Cannabinoid & $\Delta 9$-THC & $\begin{array}{c}\Delta 9- \\
\text { THCV }\end{array}$ & $\begin{array}{c}\Delta 9- \\
\text { THCA }\end{array}$ & $\begin{array}{c}\Delta 9- \\
\text { THCVA }\end{array}$ & CBD & CBDA & CBDV & CBG & CBGA & CBGV & СВС & CBN \\
\hline $\begin{array}{l}\text { Antioxidant } \\
\text { activity }\end{array}$ & $\stackrel{+}{+}$ & $\stackrel{+}{[116]}$ & $\stackrel{+}{+}$ & $\stackrel{+}{[116]}$ & $\stackrel{+}{+}$ & $\stackrel{+}{+}$ & $\stackrel{+}{+}$ & $\begin{array}{c}+ \\
{[62]}\end{array}$ & $\begin{array}{c}+ \\
{[62]}\end{array}$ & & & $\begin{array}{c}+ \\
{[62]}\end{array}$ \\
\hline $\begin{array}{c}\text { Antibacterial } \\
\text { gram-positive } \\
\text { activity }\end{array}$ & $\begin{array}{c}+ \\
{[61,119,} \\
120]\end{array}$ & $\stackrel{+}{+}$ & $\stackrel{+}{+}$ & $\stackrel{+}{+}$ & $\begin{array}{c}+ \\
{[61,119} \\
120]\end{array}$ & $\stackrel{+}{+}$ & $\stackrel{+}{+}$ & $\begin{array}{c}+ \\
{[61,119} \\
120]\end{array}$ & $\stackrel{+}{+}$ & $\stackrel{+}{+}$ & $\begin{array}{c}+ \\
{[119-} \\
121]\end{array}$ & $\stackrel{+}{+}$ \\
\hline $\begin{array}{l}\text { Photoprotectant } \\
\text { activity }\end{array}$ & {$\left[\begin{array}{c}- \\
{[123]}\end{array}\right.$} & & & & $\begin{array}{c}+ \\
\text { (UVA) } \\
{[123]}\end{array}$ & & & $\begin{array}{c}+ \\
(\mathrm{UVA}) \\
{[123]}\end{array}$ & & & $\begin{array}{c}+ \\
(\mathrm{UVB}) \\
{[123]}\end{array}$ & $\begin{array}{c}+ \\
(\mathrm{UVB}) \\
{[123]}\end{array}$ \\
\hline
\end{tabular}

Because of its wide range of effects, formulation technologies are being developed to ensure better topical delivery of CBD for medical and cosmetic use [124-128].

\section{Hemp Seed Oil}

\subsection{Generalities}

Hemp Seed Oil is extracted from the seeds by cold-pressed extraction or supercritical $\mathrm{CO}_{2}$ for better stability [129]. It represents about $30 \%$ of the raw material [130]. The cultivars employed and the growth condition of the plant directly impact the composition of the oil. The oil contains linoleic acid (55.41-59.64\%), $\alpha$-linoleic acid (16.51-20.40\%), oleic acid (11.40-15.88\%), palmitic acid (6.08-6.82\%), and stearic acid (2.34-2.67\%) [8]. Furthermore $25-35 \%$ of the oil weight are proteins, $10-15 \%$ are fibers, and $20-30 \%$ are carbohydrates [131]. Certain strains also contain up to $4 \%$ of $\gamma$-linoleic acid [129]. Sometimes, Hemp Seed Oil can also be classified by saturated, monounsaturated, and poly-unsaturated acids or by omega-3, omega-6, omega-9 acids composition:

- $\quad 80.0 \%$ poly-unsaturated acids, $10.8 \%$ monounsaturated acids, and $9.2 \%$ saturated acids [132].

- $\quad 59.6 \%$ omega- 6 acids, $29.7 \%$ of omega- 3 acids, and $10.8 \%$ omega- 9 acids [132].

Hemp Seed Oil, as an oil rich in essential fatty acids (ELA), has an action on atopic dermatitis, psoriasis, and particularly acne. Many studies find conflicting results, which indicates that the actions of ELA are dose-dependant and length-dependant [133]. Both $\alpha$ linolenic acid and linoleic acids reduce UV damage and hyperpigmentation [134]. Clinical evidence highlights the positive hydrating and anti-aging effect of essentials fatty acids on the skin for oral use [135]. A favorable portion of fatty acids in Hemp Seed Oil improves the gliding of a skin care cream and the smoothness of the skin [4,136]. Moreover, Hemp Seed Oil is a non-comedogenic [137] dry oil that does not leave a greasy and sticky layer on the skin [137]. As a result, formulations have been developed with Hemp Seed Oil as long-term moisturizing patches [138] and stable emulsions in sunscreen cosmetics [5,136]. Hemp Seed Oil's global antioxidant activity can be measured by 2,2-diphenyl-1-picrylhydrazyl (DPPH) and 2,20-azino-bis-(3-ethylbenzthiazoline-6-sulfonic acid) (ABTS) test [130]. DPPH leads to $60-65 \%$ scavenging activity and ABTS leads to $40-88 \%$ scavenging activity $[130,132]$.

Hemp Seed Oil extraction leads to byproducts of seed paste which can be recycled as a dermo-cosmetic agent by use of eco-friendly processes: Ultrasound-Assisted Extraction or Supercritical Fluid Extraction. These pastes contain 14 bioactive metabolites: seven cannabinoid acid derivates, four lignamides, two amides, and a phenolic acid. The paste showed more than $80 \%$ of inhibition for the collagenase enzyme. The global antioxidant activity was measured by DPPH; it is up to $50 \%$ of radical scavenging [9]. 


\subsection{Biological Value of the Minor Compounds of Hemp Seed Oil \\ 6.2.1. Essential Fatty Acids}

Linoleic acid, $\alpha$-linoleic acid and $\gamma$-linoleic acid are considered ELA. These compounds are required for the wealth being but not synthesized by our body [139]. Because of the competition of omega- 6 and omega- 3 family acids for the $\Delta-6$ desaturase enzyme, the ratio of their consumption is important. Hemp Seed Oil fits perfectly in the ( $\omega-6 / \omega-3)$ ideal ratio which is between $2: 1$ to 3:1 this ratio [140].

Linoleic acid is involved in the biosynthesis of leukotrienes, endocannabinoids, and arachidonic acid which is the main precursor of prostaglandins. Linoleic acid is also engaged in $\beta$-oxidation in the sebaceous gland to synthesize squalene and wax esters. When skin's linoleic acid levels are low, epidermal barrier function is impaired, the comedone wall becomes permeable to inflammatory substances, resulting in a comedogenic effect $[134,141]$.

$\alpha$-linoleic acid is a compound in cell and mitochondrial membranes that modifies cell transport and signaling through the lipid layers. The $\alpha$-linolenic acid metabolites permit the synthesis of the anti-inflammatory prostaglandin and leukotriene [134]. Therefore, $\alpha$-linoleic acid is involved in barrier function maintenance, the stratum corneum maturation and differentiation, lamellar body formation, lipoxygenase, and pro-inflammatory eicosanoid inhibition, cytokine suppression, inhibition of mast cell degranulation, and modulation of other immune cells [133].

The $\gamma$-linoleic acid decreases the production of pro-inflammatory leukotriene B4 by increasing the concentration of dihomo- $\gamma$-linoleic acid in the skin [142].

\subsubsection{Carotenoids}

Hemp Seed Oil contains carotenoids, particularly $\beta$-carotene, lutein, and zeaxanthin $[7,143]$. These carotenoids exhibit antioxidant and UV-filtering properties because of their high solubility in the lipid bilayer membrane [144]. Therefore, $\beta$-carotene inhibits the UVBinduced upregulation of pro-inflammatory cytokines, resulting in an anti-inflammatory action $[145,146]$. Carotenoids improve skin hydration, promote skin regeneration, and stimulate fibroblasts to produce collagen and elastin [137].

\subsubsection{Tocopherols}

Hemp Seed Oil contains $\alpha$-tocopherol, $\beta$-tocopherol, $\delta$-tocopherol, $\gamma$ tocopherol $[130,147]$. $\gamma$-tocopherol is the principal isomer with $85-91 \%$ of the tocopherols [143]. It is the main antioxidant of the Hemp Seed Oil and is responsible for most of the global antioxidant and anti-aging activities [7].

\subsubsection{Phytosterols}

Hemp Seed Oil contains phytosterols that inhibit the matrix metalloproteinases. The matrix metalloproteinase action inhibits COL1A1 and COL1A2 genes responsible for collagen synthesis. Therefore phytosterols permit better collagen synthesis and prevent skin aging [148].

\subsubsection{Chlorophyll}

Chlorophyll is surprisingly high in Hemp Seed Oil, it varies between $100 \mu \mathrm{g} / \mathrm{g}$ to $230 \mu \mathrm{g} / \mathrm{g}$, depending on the extraction method, which is 11 times higher than in Flax Seed Oil and 88 times higher than in Canola Oil [143]. This component is responsible for the green color of the Hemp Seed Oil. The chlorophyll has beneficial action for woundhealing by promoting tissue growth, and by its antibacterial activity [149]. Therefore, it is an interesting ingredient in topical application against acne [150,151], eczema, and ulcers [152].

\subsubsection{Flavonoids}

There are 26 flavonoids in Hemp. Orientin, vitexin, luteolin-7-O-glucoside, and apigenin-7-O-glucoside are the main flavonoids in Hemp [153]. It also contains Quercetin 
which exerts a strong antioxidant effect [154]. There are 3 new flavonoids exclusive to Cannabis called Cannflavins (Cannflavin A, Cannflavin B, and Cannflavin C). Cannflavins are present in the leaves and the flower of Hemp [11]. Cannflavin A's anti-inflammatory activity is 30 times stronger than Aspirin [155]. This anti-inflammatory effect is explained by the inhibition of the molecular targets microsomal prostaglandin E synthase-1 (mPGES-1) and 5-lipoxygenase (5-LO) [156].

\subsubsection{Terpenes}

More than 200 terpenes have been identified in Cannabis sativa L. [10]. Terpenes are responsible for the aromatic properties of the plant [157]. Terpenes are secreted and stored inside the glandular trichomes with cannabinoids [158]. The most concentrated terpenes in Cannabis are $\alpha$-pinene, $\beta$-pinene, $\alpha$-humulene, $\beta$-caryophyllene, $\beta$-myrcene, limonene, and linalool. Each strain conducts to different chemotypes of terpenes, a strain rarely contains more than 50 terpenes [10,157-160]. All these compounds have a biodynamic effect [161] (see Table 5.), but $\beta$-caryophyllene has the particularity to bind specifically with the CB2.

Table 5. Biodynamic effect of the main terpenes found in Cannabis sativa L.

\begin{tabular}{|c|c|}
\hline Terpene & Biodynamic Effect \\
\hline$\beta$-caryophyllene & $\begin{array}{l}\text { Anti-viral, antioxidant, anti-inflammatory, anticancerogenic, analgesic, } \\
\text { anxiolytic, antibacterial, antifungal, antiproliferation, antidepressant, } \\
\text { neuroprotective and gastroprotective [161] }\end{array}$ \\
\hline$\beta$-myrcene & $\begin{array}{l}\text { Antioxidant, anti-inflammatory, anticancerogenic, analgesic, sedative, } \\
\text { muscle relaxant and antipsychotic [161] }\end{array}$ \\
\hline$\alpha$-pinene & $\begin{array}{l}\text { Anti-inflammatory, antibacterial, bronchodilator, antiseptic and } \\
\text { gastroprotective [161] }\end{array}$ \\
\hline$\beta$-pinene & Antiseptic [161] \\
\hline$\alpha$-humulene & Anti-inflammatory, anticancerogenic, antifungal and analgesic [161] \\
\hline limonene & $\begin{array}{l}\text { Antibacterial, antifungal, antimicrobial, antiproliferative, anxiolytic, } \\
\text { antidepressant, antispasmodic and gastroprotective [161] }\end{array}$ \\
\hline linalool & $\begin{array}{l}\text { Antineoplastic, antiepileptic, anticonvulsant, sedative, anxiolytic, } \\
\text { antipsychotic, analgesic, antidepressant and anesthetic [161] }\end{array}$ \\
\hline
\end{tabular}

\subsection{The Entourage Effect}

The term «entourage effect» refers to the capacity of two or more cannabinoids or noncannabinoids to have a better combined synergistic effect than when taken separately [162]. The concept was introduced in 1998 by Mechoulam [163].

Studies consider 4 types of synergies: multi-target effects (each component affects multiple targets), pharmacokinetic effects (components can increase the solubility or the resorption rate of an active), agent interactions affecting bacterial resistance, and modulation of adverse effects and toxicity [164].

The THC and CBD 1:1 combination is the most known case of entourage effect: it alleviates the adverse effects of pure THC [162].

Currently, evidence in favor of an entourage effect of Terpenes or Flavonoids combined with THC is contradictory, further studies are warranted to determine to which extent this concept is relevant $[165,166]$.

\section{Conclusions}

The cannabinoids contained in Cannabis sativa L. are of dermatological interest for treating most inflammatory skin conditions as well as skin cancer. We now have a better understanding of the endocannabinoid system of the skin and the possible mode of action of cannabinoids. However, the focus of research remains on CBD and THC, which 
have demonstrated therapeutic value, but at the expense of studying the action of other cannabinoids.

As for their use in cosmetics, CBD, CBC, THCV and CBDV have potential for formulations for acne-prone skin, while CBG and CBGV are promising for regulating sebum production in dry skin. CBN and CBD also appear to be of interest for sunscreens. Almost all cannabinoids have an antibacterial and antioxidant action which is a good added value. Moreover, the immunoregulatory effects of cannabinoids seem interesting for sensitive skin. It should be noted, however, that their safety for regular use has not yet been demonstrated, apart from CBD. Further studies are warranted in this regard.

Hemp Seed Oil is interesting because of its content of flavonoids, terpenes, carotenoids and phytosterols which ensure its anti-inflammatory and anti-aging action. In addition, its $\omega-6 / \omega-3$ content is ideal for the skin. It is a rapidly absorbed and non-comedogenic oil. It naturally contains tocopherol and chlorophyll. This oil is therefore of interest for formulations for all skin types, especially sensitive skin, and as a sun cream. It has potential for anti-ageing formulations.

Author Contributions: Conceptualization, L.M. and L.R.; methodology, L.R.; validation, L.R.; investigation, L.M.; data curation, L.M.; writing —original draft preparation, L.M.; writing—review and editing, L.M. and L.R.; visualization, L.M.; supervision, L.R.; project administration, L.R. All authors have read and agreed to the published version of the manuscript.

Funding: This research received no external funding.

Institutional Review Board Statement: Not applicable.

Informed Consent Statement: Not applicable.

Data Availability Statement: The data presented in this study are available within the article.

Conflicts of Interest: The authors declare no conflict of interest. The funders had no role in the design of the study; in the collection, analyses, or interpretation of data; in the writing of the manuscript, or in the decision to publish the results.

\section{References}

1. Small, E. Evolution and Classification of Cannabis sativa (Marijuana, Hemp) in Relation to Human Utilization. Bot. Rev. 2015, 81, 189-294. [CrossRef]

2. Grof, C.P.L. Cannabis, from plant to pill. Br. J. Clin. Pharmacol. 2018, 84, 2463-2467. [CrossRef] [PubMed]

3. Sheriff, T.; Lin, M.J.; Dubin, D.; Khorasani, H. The potential role of cannabinoids in dermatology. J. Dermatol. Treat. 2019, 31, 839-845. [CrossRef]

4. Vogl, C.R.; Mölleken, H.; Lissek-Wolf, G.; Surböck, A.; Kobert, J. Hemp (Cannabis sativa L.) as a resource for green cosmetics: Yield of seed and fatty acid compositions of 20 varieties under the growing conditions of organic farming in Austria. J. Ind. Hemp 2004, 9, 51-68. [CrossRef]

5. Huang, Y.; Pei, L.; Gu, X.; Wang, J. Study on the Oxidation Products of Hemp Seed Oil and its Application in Cosmetics. Tenside Surfactants Deterg. 2020, 57, 230-236. [CrossRef]

6. Scheau, C.; Badarau, I.A.; Mihai, L.-G.; Scheau, A.-E.; Costache, D.O.; Constantin, C.; Calina, D.; Caruntu, C.; Costache, R.S.; Caruntu, A. Cannabinoids in the Pathophysiology of Skin Inflammation. Molecules 2020, 25, 652. [CrossRef] [PubMed]

7. Irakli, M.; Tsaliki, E.; Kalivas, A.; Kleisiaris, F.; Sarrou, E.; Cook, C.M. Effect of Genotype and Growing Year on the Nutritional, Phytochemical, and Antioxidant Properties of Industrial Hemp (Cannabis sativa L.) Seeds. Antioxidants 2019, 8, 491. [CrossRef]

8. Kiralan, M.; Gül, V.; Kara, S.M. Fatty acid composition of hempseed oils from different locations in Turkey. Span. J. Agric. Res. 2010, 8, 385. [CrossRef]

9. Michailidis, D.; Angelis, A.; Nikolaou, P.; Mitakou, S.; Skaltsounis, A. Exploitation of Vitis vinifera, Foeniculum vulgare, Cannabis sativa and Punica granatum By-Product Seeds as Dermo-Cosmetic Agents. Molecules 2021, 26, 731. [CrossRef]

10. Bakro, F.; Jedryczka, M.; Wielgusz, K.; Sgorbini, B.; Inchingolo, R.; Cardenia, V. Simultaneous determination of terpenes and cannabidiol in hemp (Cannabis sativa L.) by fast gas chromatography with flame ionization detection. J. Sep. Sci. 2020, 43, 2817-2826. [CrossRef]

11. Werz, O.; Seegers, J.; Schaible, A.M.; Weinigel, C.; Barz, D.; Koeberle, A.; Allegrone, G.; Pollastro, F.; Zampieri, L.; Grassi, G.; et al. Cannflavins from hemp sprouts, a novel cannabinoid-free hemp food product, target microsomal prostaglandin E2 synthase-1 and 5-lipoxygenase. PharmaNutrition 2014, 2, 53-60. [CrossRef]

12. Klumpers, L.; Thacker, D.L. A Brief Background on Cannabis: From Plant to Medical Indications. J. AOAC Int. 2019, 102, 412-420. [CrossRef] 
13. Chandra, S.; Lata, H.; Khan, I.A.; ElSohly, M.A. Cannabis sativa L.: Botany and Horticulture. In Cannabis sativa L.-Botany and Biotechnology; Springer: Cham, Switzerland, 2017; pp. 79-100. [CrossRef]

14. Addo, P.W.; Brousseau, V.D.; Morello, V.; MacPherson, S.; Paris, M.; Lefsrud, M. Cannabis chemistry, post-harvest processing methods and secondary metabolite profiling: A review. Ind. Crop. Prod. 2021, 170, 113743. [CrossRef]

15. EB, R. History of cannabis and its preparations in saga, science, and sobriquet. Chem. Biodivers. 2007, 4, 1614-1648. [CrossRef]

16. Bíró, T.; Tóth, B.I.; Haskó, G.; Paus, R.; Pacher, P. The endocannabinoid system of the skin in health and disease: Novel perspectives and therapeutic opportunities. Trends Pharmacol. Sci. 2009, 30, 411-420. [CrossRef]

17. del Río, C.; Millán, E.; García, V.; Appendino, G.; DeMesa, J.; Muñoz, E. The endocannabinoid system of the skin. A potential approach for the treatment of skin disorders. Biochem. Pharmacol. 2018, 157, 122-133. [CrossRef]

18. Caterina, M.J. TRP Channel Cannabinoid Receptors in Skin Sensation, Homeostasis, and Inflammation. ACS Chem. Neurosci. 2014, 5, 1107-1116. [CrossRef]

19. Tüting, T.; Gaffal, E. Regulatory Role of Cannabinoids for Skin Barrier Functions and Cutaneous. Inflammation 2017, 543-549. [CrossRef]

20. Mehrpouya-Bahrami, P.; Chitrala, K.N.; Ganewatta, M.S.; Tang, C.; Murphy, E.A.; Enos, R.T.; Velazquez, K.T.; McCellan, J.; Nagarkatti, M.; Nagarkatti, P. Blockade of CB1 cannabinoid receptor alters gut microbiota and attenuates inflammation and diet-induced obesity. Sci. Rep. 2017, 7, 1-16. [CrossRef]

21. Jorgačević, B.; Vučević, D.; Samardžić, J.; MladenoviĆ, D.; Vesković, M.; Vukićević, D.; Ješić, R.; Radosavljević, T. The Effect of CB1 Antagonism on Hepatic Oxidative/Nitrosative Stress and Inflammation in Nonalcoholic Fatty Liver Disease. Curr. Med. Chem. 2020, 28, 169-180. [CrossRef]

22. Thapa, D.; Cairns, E.A.; Szczesniak, A.-M.; Kulkarni, P.M.; Straiker, A.J.; Thakur, G.A.; Kelly, M.E.M. Allosteric Cannabinoid Receptor 1 (CB1) Ligands Reduce Ocular Pain and Inflammation. Molecules 2020, 25, 417. [CrossRef]

23. Du, Y.; Ren, P.; Wang, Q.; Jiang, S.-K.; Zhang, M.; Li, J.-Y.; Wang, L.-L.; Guan, D.-W. Cannabinoid 2 receptor attenuates inflammation during skin wound healing by inhibiting M1 macrophages rather than activating M2 macrophages. J. Inflamm. 2018, 15, 25. [CrossRef]

24. Prandi, C.; Blangetti, M.; Namdar, D.; Koltai, H. Structure-Activity Relationship of Cannabis Derived Compounds for the Treatment of Neuronal Activity-Related Diseases. Molecules 2018, 23, 1526. [CrossRef]

25. Guerrero-Alba, R.; Barragan-Iglesias, P.; González-Hernández, A.; Valdez-Moráles, E.E.; Granados-Soto, V.; Condés-Lara, M.; Rodríguez, M.G.; Marichal-Cancino, B.A. Some Prospective Alternatives for Treating Pain: The Endocannabinoid System and Its Putative Receptors GPR18 and GPR55. Front. Pharmacol. 2019, 9, 1496. [CrossRef] [PubMed]

26. Morales, P.; Lago-Fernandez, A.; Hurst, D.P.; Sotudeh, N.; Brailoiu, E.; Reggio, P.H.; Abood, M.E. Jagerovic NTherapeutic Exploitation of GPR18: Beyond the Cannabinoids? J. Med. Chem. 2020, 63, 14216-14227. [CrossRef]

27. Yang, H.; Zhou, J.; Lehmann, C. GPR55-A putative "type 3" cannabinoid receptor in inflammation. J. Basic Clin. Physiol. Pharmacol. 2016, 27, 297-302. [CrossRef]

28. Perez-Gomez, E.; Andradas, C.; Flores, J.M.; Quintanilla, M.; Paramio, J.M.; Guzmán, M.; Sanchez, C. The orphan receptor GPR55 drives skin carcinogenesis and is upregulated in human squamous cell carcinomas. Oncogene 2012, 32, 2534-2542. [CrossRef]

29. Fabisiak, A.; Fabisiak, N.; Mokrowiecka, A.; Malecka-Panas, E.; Jacenik, D.; Kordek, R.; Zielińska, M.; Kieć-Kononowicz, K.; Fichna, J. Novel selective agonist of GPR18, PSB-KK-1415 exerts potent anti-inflammatory and anti-nociceptive activities in animal models of intestinal inflammation and inflammatory pain. Neurogastroenterol. Motil. 2020, 33, e14003. [CrossRef]

30. Qin, Y.; Verdegaal, E.M.E.; Siderius, M.; Bebelman, J.P.; Smit, M.J.; Leurs, R.; Willemze, R.; Tensen, C.P.; Osanto, S. Quantitative expression profiling of G-protein-coupled receptors (GPCRs) in metastatic melanoma: The constitutively active orphan GPCR GPR18 as novel drug target. Pigment. Cell Melanoma Res. 2011, 24, 207-218. [CrossRef]

31. Sugiura, T.; Kobayashi, Y.; Oka, S.; Waku, K. Biosynthesis and degradation of anandamide and 2-arachidonoylglycerol and their possible physiological significance. Prostaglandins Leukot. Essent. Fat. Acids 2002, 66, 173-192. [CrossRef]

32. Di Marzo, V. Endocannabinoids: Synthesis and degradation. Rev. Physiol. Biochem. Pharmacol. 2006, 160, 1-24. [CrossRef]

33. Petrosino, S.; Di Marzo, V. The pharmacology of palmitoylethanolamide and first data on the therapeutic efficacy of some of its new formulations. Br. J. Pharmacol. 2016, 174, 1349-1365. [CrossRef] [PubMed]

34. Yesilyurt, O.; Cayirli, M.; Sakin, Y.S.; Seyrek, M.; Akar, A.; Dogrul, A. Systemic and spinal administration of FAAH, MAGL inhibitors and dual FAAH/MAGL inhibitors produce antipruritic effect in mice. Arch. Dermatol. Res. 2016, 308, 335-345. [CrossRef] [PubMed]

35. Schlosburg, J.E.; Boger, D.L.; Cravatt, B.F.; Lichtman, A.H. Endocannabinoid Modulation of Scratching Response in an Acute Allergenic Model: A New Prospective Neural Therapeutic Target for Pruritus. J. Pharmacol. Exp. Ther. 2009, 329, 314-323. [CrossRef]

36. Sasso, O.; Summa, M.; Armirotti, A.; Pontis, S.; De Mei, C.; Piomelli, D. The N-Acylethanolamine Acid Amidase Inhibitor ARN077 Suppresses Inflammation and Pruritus in a Mouse Model of Allergic Dermatitis. J. Investig. Dermatol. 2018, 138, 562-569. [CrossRef]

37. Nordlind, K.; Azmitia, E.; Slominski, A. The skin as a mirror of the soul: Exploring the possible roles of serotonin. Exp. Dermatol. 2008, 17, 301-311. [CrossRef]

38. Clapham, D.E.; Runnels, L.; Strübing, C. The trp ion channel family. Nat. Rev. Neurosci. 2001, 2, 387-396. [CrossRef] 
39. Rigamonti, E.; Chinetti, G.; Staels, B. Regulation of Macrophage Functions by PPAR- $\alpha$, PPAR- $\gamma$, and LXRs in Mice and Men. Arter. Thromb. Vasc. Biol. 2008, 28, 1050-1059. [CrossRef]

40. Bagood, M.; Isseroff, R. TRPV1: Role in Skin and Skin Diseases and Potential Target for Improving Wound Healing. Int. J. Mol. Sci. 2021, 22, 6135. [CrossRef]

41. Muller, C.; Morales, P.; Reggio, P.H. Cannabinoid Ligands Targeting TRP Channels. Front. Mol. Neurosci. 2019, 11, 487. [CrossRef]

42. Bonchak, J.G.; Swerlick, R.A. Emerging therapies for atopic dermatitis: TRPV1 antagonists. J. Am. Acad. Dermatol. 2018, 78, S63-S66. [CrossRef]

43. Ishii, T.; Uchida, K.; Hata, S.; Hatta, M.; Kita, T.; Miyake, Y.; Okamura, K.; Tamaoki, S.; Ishikawa, H.; Yamazaki, J. TRPV2 channel inhibitors attenuate fibroblast differentiation and contraction mediated by keratinocyte-derived TGF- $\beta 1$ in an in vitro wound healing model of rats. J. Dermatol. Sci. 2018, 90, 332-342. [CrossRef] [PubMed]

44. Tóth, K.F.; Ádám, D.; Bíró, T.; Oláh, A. Cannabinoid signaling in the skin: Therapeutic potential of the "c(ut)annabinoid" system. Molecules 2019, 24, 918. [CrossRef]

45. Cao, X.; Yang, F.; Zheng, J.; Wang, K. Intracellular Proton-mediated Activation of TRPV3 Channels Accounts for the Exfoliation Effect of $\alpha$-Hydroxyl Acids on Keratinocytes. J. Biol. Chem. 2012, 287, 25905-25916. [CrossRef]

46. Qu, Y.; Wang, G.; Sun, X.; Wang, K. Inhibition of the Warm Temperature-Activated Ca2+-Permeable Transient Receptor Potential Vanilloid TRPV3 Channel Attenuates Atopic Dermatitis. Mol. Pharmacol. 2019, 96, 393-400. [CrossRef]

47. Sokabe, T.; Tominaga, M. The TRPV4 cation channel. Commun. Integr. Biol. 2010, 3, 619-621. [CrossRef]

48. Goswami, R.; Cohen, J.; Sharma, S.; Zhang, D.X.; Lafyatis, R.; Bhawan, J.; Rahaman, S.O. TRPV4 ION Channel Is Associated with Scleroderma. J. Investig. Dermatol. 2017, 137, 962-965. [CrossRef]

49. Maglie, R.; de Araujo, D.S.M.; Antiga, E.; Geppetti, P.; Nassini, R.; De Logu, F. The Role of TRPA1 in Skin Physiology and Pathology. Int. J. Mol. Sci. 2021, 22, 3065. [CrossRef]

50. Borrelli, F.; Pagano, E.; Romano, B.; Panzera, S.; Maiello, F.; Coppola, D.; De Petrocellis, L.; Buono, L.; Orlando, P.; Izzo, A.A. Colon carcinogenesis is inhibited by the TRPM8 antagonist cannabigerol, a Cannabis-derived non-psychotropic cannabinoid. Carcinogenesis 2014, 35, 2787-2797. [CrossRef]

51. Dubrac, S.; Schmuth, M. PPAR-alpha in cutaneous inflammation. Dermato-Endocrinology 2011, 3, 23-26. [CrossRef] [PubMed]

52. Mastrofrancesco, A.; Kovacs, D.; Sarra, M.; Bastonini, E.; Cardinali, G.; Aspite, N.; Camera, E.; Chavatte, P.; Desreumaux, P.; Monteleone, G.; et al. Preclinical Studies of a Specific PPAR $\gamma$ Modulator in the Control of Skin Inflammation. J. Investig. Dermatol. 2014, 134, 1001-1011. [CrossRef]

53. Ghosh, A.K. Pharmacological activation of PPAR- $\gamma$ : A potential therapy for skin fibrosis. Int. J. Dermatol. 2020, 60, 376-383. [CrossRef] [PubMed]

54. Gonzalez, E.G.; Selvi, E.; Balistreri, E.; Akhmetshina, A.; Palumbo, K.; Lorenzini, S.; Lazzerini, P.E.; Montilli, C.; Capecchi, P.L.; Lucattelli, M.; et al. Synthetic cannabinoid ajulemic acid exerts potent antifibrotic effects in experimental models of systemic sclerosis. Ann. Rheum. Dis. 2012, 71, 1545-1551. [CrossRef]

55. Correia-Sá, I.; Paiva, A.; Carvalho, C.M.; Vieira-Coelho, M.A. Cutaneous endocannabinoid system: Does it have a role on skin wound healing bearing fibrosis? Pharmacol. Res. 2020, 159, 104862. [CrossRef] [PubMed]

56. Martins, A.M.; Ascenso, A.; Ribeiro, H.M.; Marto, J. Current and Future Therapies for Psoriasis with a Focus on Serotonergic Drugs. Mol. Neurobiol. 2020, 57, 2391-2419. [CrossRef] [PubMed]

57. Martins, A.M.; Ascenso, A.; Ribeiro, H.M.; Marto, J. The Brain-Skin Connection and the Pathogenesis of Psoriasis: A Review with a Focus on the Serotonergic System. Cells 2020, 9, 796. [CrossRef] [PubMed]

58. Kawana, S.; Kato, Y.; Omi, T. Efficacy of a 5-HT1a receptor agonist in atopic dermatitis. Clin. Exp. Dermatol. 2010, 35, 835-840. [CrossRef]

59. Sadiq, A.; Menchetti, I.; Shah, A.; Jeschke, M.G.; Belo, C.; Carlos-Alcalde, W.; Hayat, M.Q.; Amini-Nik, S. 5-HT1A Receptor Function Makes Wound Healing a Happier Process. Front. Pharmacol. 2018, 9, 1406. [CrossRef]

60. Wetterberg, J.; Taher, C.; Azmitia, E.; Elnour, H. Time-dependent modulation of serotonin and its receptors $1 \mathrm{~A}$ and 2A expression in allergic contact dermatitis. J. Eur. Acad. Dermatol. Venereol. 2011, 25, 1200-1205. [CrossRef]

61. Baswan, S.M.; Klosner, A.E.; Glynn, K.; Rajgopal, A.; Malik, K.; Yim, S.; Stern, N. Therapeutic Potential of Cannabidiol (CBD) for Skin Health and Disorders. Clin. Cosmet. Investig. Dermatol. 2020, 13, 927-942. [CrossRef]

62. Dawidowicz, A.L.; Olszowy-Tomczyk, M.; Typek, R. CBG, CBD, $\triangle 9$-THC, CBN, CBGA, CBDA and $\triangle 9$-THCA as antioxidant agents and their intervention abilities in antioxidant action. Fitoterapia 2021, 152, 104915. [CrossRef] [PubMed]

63. Johnson, J.V.; Christensen, A.; Morgan, D.; Basso, K.B. Gas chromatography/electron ionization mass spectrometry (GC/EI-MS) for the characterization of phytocannabinoids in Cannabis sativa. Compr. Anal. Chemistry 2020, 90, 235-274. [CrossRef]

64. Site How Biosynthesis of Cannabinoids Could Impact the Cannabis Industry-New Cannabis Ventures. Available online: https:/ / www.newcannabisventures.com/how-biosynthesis-of-cannabinoids-could-impact-the-cannabis-industry/ (accessed on 12 July 2021).

65. Hartsel, J.A.; Eades, J.; Hickory, B.; Makriyannis, A. Cannabis sativa and Hemp. In Nutraceuticals: Efficacy, Safety and Toxicity; Elsevier Inc.: Amsterdam, The Netherlands, 2016; pp. 735-754. ISBN 9780128021477.

66. Brousseau, V.D.; Wu, B.-S.; MacPherson, S.; Morello, V.; Lefsrud, M. Cannabinoids and Terpenes: How Production of PhotoProtectants Can Be Manipulated to Enhance Cannabis sativa L. Phytochemistry. Front. Plant Sci. 2021, 12. [CrossRef] 
67. Turner, S.E.; Williams, C.M.; Iversen, L.; Whalley, B.J. Molecular Pharmacology of Phytocannabinoids. Phytocannabinoids 2017, 103, 61-101. [CrossRef]

68. Zagzoog, A.; Mohamed, K.A.; Kim, H.J.J.; Kim, E.D.; Frank, C.S.; Black, T.; Jadhav, P.D.; Holbrook, L.A.; Laprairie, R.B. In vitro and in vivo pharmacological activity of minor cannabinoids isolated from Cannabis sativa. Sci. Rep. 2020, 10, 1-13. [CrossRef]

69. Palomares, B.; Garrido-Rodriguez, M.; Gonzalo-Consuegra, C.; Gómez-Cañas, M.; Saen-Oon, S.; Soliva, R.; Collado, J.A.; Fernández-Ruiz, J.; Morello, G.; Calzado, M.A.; et al. $\Delta 9$-Tetrahydrocannabinolic acid alleviates collagen-induced arthritis: Role of PPAR $\gamma$ and CB 1 receptors. Br. J. Pharmacol. 2020, 177, 4034-4054. [CrossRef]

70. Oláh, A.; Tóth, B.I.; Borbíró, I.; Sugawara, K.; Szöllõsi, A.G.; Czifra, G.; Pál, B.; Ambrus, L.; Kloepper, J.; Camera, E.; et al. Cannabidiol exerts sebostatic and antiinflammatory effects on human sebocytes. J. Clin. Invest. 2014, 124, 3713-3724. [CrossRef]

71. Steenson, S.; Chambers, L. Cannabidiol: A budding industry! Nutr. Bull. 2019, 44, 228-240. [CrossRef]

72. Rosenthaler, S.; Pöhn, B.; Kolmanz, C.; Nguyen Huu, C.; Krewenka, C.; Huber, A.; Kranner, B.; Rausch, W.D.; Moldzio, R. Differences in receptor binding affinity of several phytocannabinoids do not explain their effects on neural cell cultures. Neurotoxicol. Teratol. 2014, 46, 49-56. [CrossRef]

73. Nachnani, R.; Raup-Konsavage, W.M.; Vrana, K.E. The Pharmacological Case for Cannabigerol. J. Pharmacol. Exp. Ther. 2020, 376, 204-212. [CrossRef]

74. Navarro, G.; Varani, K.; Lillo, A.; Vincenzi, F.; Rivas-Santisteban, R.; Raïch, I.; Reyes-Resina, I.; Ferreiro-Vera, C.; Borea, P.A.; de Medina, V.S.; et al. Pharmacological data of cannabidiol- and cannabigerol-type phytocannabinoids acting on cannabinoid CB1, CB2 and CB1/CB2 heteromer receptors. Pharmacol. Res. 2020, 159, 104940. [CrossRef] [PubMed]

75. Udoh, M.; Santiago, M.; Devenish, S.; McGregor, I.S.; Connor, M. Cannabichromene is a cannabinoid CB 2 receptor agonist. Br. J. Pharmacol. 2019, 176, 4537-4547. [CrossRef]

76. dos Santos, R.G.; Hallak, J.E.C.; Crippa, J.A.S. Neuropharmacological Effects of the Main Phytocannabinoids: A Narrative Review. Cannabinoids Neuropsychiatr. Disord. 2020, 1264, 29-45. [CrossRef]

77. McHugh, D.; Page, J.; Dunn, E.; Bradshaw, H.B. $\triangle$ 9-tetrahydrocannabinol and N-arachidonyl glycine are full agonists at GPR18 receptors and induce migration in human endometrial HEC-1B cells. Br. J. Pharmacol. 2012, 165, 2414-2424. [CrossRef]

78. Zhong, N. Cannabinol Inhibits Proliferation and Induces Cell Cycle Arrest and Apoptosis in Glioblastoma, Hepatocellular Carcinoma and Breast Cancer Cells. Master's Thesis, University of Lethbridge, Lethbridge, Alta, 2020.

79. Anavi-Goffer, S.; Baillie, G.; Irving, A.J.; Gertsch, J.; Greig, I.R.; Pertwee, R.G.; Ross, R.A. Modulation of l- $\alpha$-Lysophosphatidylinositol/ GPR55 Mitogen-activated Protein Kinase (MAPK) Signaling by Cannabinoids. J. Biol. Chem. 2012, 287, 91-104. [CrossRef]

80. Ryberg, E.; Larsson, N.; Sjögren, S.; Hjorth, S.; Hermansson, N.O.; Leonova, J.; Elebring, T.; Nilsson, K.; Drmota, T.; Greasley, P.J. The orphan receptor GPR55 is a novel cannabinoid receptor. Br. J. Pharmacol. 2007, 152, 1092-1101. [CrossRef]

81. De Petrocellis, L.; Ligresti, A.; Moriello, A.S.; Allarà, M.; Bisogno, T.; Petrosino, S.; Stott, C.G.; Di Marzo, V. Effects of cannabinoids and cannabinoid-enrichedCannabisextracts on TRP channels and endocannabinoid metabolic enzymes. Br. J. Pharmacol. 2011, 163, 1479-1494. [CrossRef]

82. De Petrocellis, L.; Orlando, P.; Moriello, A.S.; Aviello, G.; Stott, C.; Izzo, A.; Di Marzo, V. Cannabinoid actions at TRPV channels: Effects on TRPV3 and TRPV4 and their potential relevance to gastrointestinal inflammation. Acta Physiol. 2011, 204, 255-266. [CrossRef]

83. O'Sullivan, S.E. An update on PPAR activation by cannabinoids. Br. J. Pharmacol. 2016, 173, 1899-1910. [CrossRef]

84. Palomares, B.; Ruiz-Pino, F.; Garrido-Rodriguez, M.; Prados, M.E.; Sánchez-Garrido, M.A.; Velasco, I.; Vazquez, M.J.; Nadal, X.; Ferreiro-Vera, C.; Morrugares, R.; et al. Tetrahydrocannabinolic acid A (THCA-A) reduces adiposity and prevents metabolic disease caused by diet-induced obesity. Biochem. Pharmacol. 2020, 171, 113693. [CrossRef] [PubMed]

85. D'Aniello, E.; Fellous, T.; Iannotti, F.; Gentile, A.; Allarà, M.; Balestrieri, F.; Gray, R.; Amodeo, P.; Vitale, R.M.; Di Marzo, V. Identification and characterization of phytocannabinoids as novel dual PPAR $\alpha / \gamma$ agonists by a computational and in vitro experimental approach. Biochim. et Biophys. Acta (BBA)-Gen. Subj. 2019, 1863, 586-597. [CrossRef] [PubMed]

86. Granja, A.G.; Carrillo-Salinas, F.J.; Pagani, A.; Gómez-Cañas, M.; Negri, R.; Navarrete, C.M.; Mecha, M.; Mestre, L.; Fiebich, B.L.; Cantarero, I.; et al. A Cannabigerol Quinone Alleviates Neuroinflammation in a Chronic Model of Multiple Sclerosis. J. Neuroimmune Pharmacol. 2012, 7, 1002-1016. [CrossRef] [PubMed]

87. O'Sullivan, S.E.; Sun, Y.; Bennett, A.J.; Randall, M.D.; Kendall, D.A. Time-dependent vascular actions of cannabidiol in the rat aorta. Eur. J. Pharmacol. 2009, 612, 61-68. [CrossRef] [PubMed]

88. Formato, M.; Crescente, G.; Scognamiglio, M.; Fiorentino, A.; Pecoraro, M.T.; Piccolella, S.; Catauro, M.; Pacifico, S. (-)-Cannabidiolic Acid, a Still Overlooked Bioactive Compound: An Introductory Review and Preliminary Research. Molecules 2020, 25, 2638. [CrossRef] [PubMed]

89. Braida, D.; Limonta, V.; Malabarba, L.; Zani, A.; Sala, M. 5-HT1A receptors are involved in the anxiolytic effect of $\Delta 9$ tetrahydrocannabinol and AM 404, the anandamide transport inhibitor, in Sprague-Dawley rats. Eur. J. Pharmacol. 2007, 555, 156-163. [CrossRef] [PubMed]

90. Cascio, M.G.; Zamberletti, E.; Marini, P.; Parolaro, D.; Pertwee, R.G. The phytocannabinoid, $\Delta$ 9-tetrahydrocannabivarin, can act through 5-HT1Areceptors to produce antipsychotic effects. Br. J. Pharmacol. 2015, 172, 1305-1318. [CrossRef]

91. Rock, E.M.; Sullivan, M.T.; Collins, S.A.; Goodman, H.; Limebeer, C.L.; Mechoulam, R.; Parker, L.A. Evaluation of repeated or acute treatment with cannabidiol (CBD), cannabidiolic acid (CBDA) or CBDA methyl ester (HU-580) on nausea and/or vomiting in rats and shrews. Psychopharmacology 2020, 237, 2621-2631. [CrossRef] 
92. Bolognini, D.; Rock, E.M.; Cluny, N.L.; Cascio, M.G.; Limebeer, C.L.; Duncan, M.; Stott, C.G.; Javid, F.; Parker, L.A.; Pertwee, R.G. Cannabidiolic acid prevents vomiting inSuncus murinusand nausea-induced behaviour in rats by enhancing 5-HT1Areceptor activation. Br. J. Pharmacol. 2013, 168, 1456-1470. [CrossRef] [PubMed]

93. Duggan, P.J. The Chemistry of Cannabis and Cannabinoids. Aust. J. Chem. 2021, 74, 369. [CrossRef]

94. Russo, E.; Burnett, A.; Hall, B.; Parker, K.K. Agonistic Properties of Cannabidiol at 5-HT1a Receptors. Neurochem. Res. 2005, 30, 1037-1043. [CrossRef]

95. Xiong, W.; Koo, B.-N.; Morton, R.; Zhang, L. Psychotropic and nonpsychotropic cannabis derivatives inhibit human 5-HT3A receptors through a receptor desensitization-dependent mechanism. Neuroscience 2011, 184, 28-37. [CrossRef] [PubMed]

96. PPucci, M.; Rapino, C.; Di Francesco, A.; Dainese, E.; D’Addario, C.; Maccarrone, M. Epigenetic control of skin differentiation genes by phytocannabinoids. Br. J. Pharmacol. 2013, 170, 581-591. [CrossRef] [PubMed]

97. Bickers, D.R.; Athar, M. Oxidative Stress in the Pathogenesis of Skin Disease. J. Investig. Dermatol. 2006, 126, 2565-2575. [CrossRef]

98. Cascio, M.G.; Gauson, L.A.; Stevenson, L.A.; Ross, R.A.; Pertwee, R.G. Evidence that the plant cannabinoid cannabigerol is a highly potent $\alpha 2$-adrenoceptor agonist and moderately potent 5HT1A receptor antagonist. Br. J. Pharmacol. 2010, 159, 129-141. [CrossRef]

99. Pollastro, F.; Caprioglio, D.; Prete, D.D.; Rogati, F.; Minassi, A.; Taglialatela-Scafati, O.; Munoz, E.; Appendino, G. Cannabichromene. Nat. Prod. Commun. 2018, 13, 1189-1194. [CrossRef]

100. Zamberletti, E.; Rubino, T.; Parolaro, D. Therapeutic potential of cannabidivarin for epilepsy and autism spectrum disorder. Pharmacol. Ther. 2021, 226, 107878. [CrossRef]

101. Fuziwara, S.; Suzuki, A.; Inoue, K.; Denda, M. Dopamine D2-Like Receptor Agonists Accelerate Barrier Repair and Inhibit the Epidermal Hyperplasia Induced by Barrier Disruption. J. Investig. Dermatol. 2005, 125, 783-789. [CrossRef] [PubMed]

102. Vaughn, A.R.; Davis, M.J.; Sivamani, R.K.; Isseroff, R.R. A Concise Review of the Conflicting Roles of Dopamine-1 versus Dopamine-2 Receptors in Wound Healing. Molecules 2017, 23, 50. [CrossRef] [PubMed]

103. Parrado, A.C.; Salaverry, L.S.; Mangone, F.M.; Apicella, C.E.; Gentile, T.; Canellada, A.; Rey-Roldán, E.B. Differential Response of Dopamine Mediated by $\beta$-Adrenergic Receptors in Human Keratinocytes and Macrophages: Potential Implication in Wound Healing. Neuroimmunomodulation 2017, 24, 282-291. [CrossRef]

104. Formukong, E.A.; Evans, A.T.; Evans, F.J. Analgesic and antiinflammatory activity of constituents ofCannabis sativa L. Inflammation 1988, 12, 361-371. [CrossRef] [PubMed]

105. Oláh, A.; Markovics, A.; Szabó-Papp, J.; Szabó, P.T.; Stott, C.; Zouboulis, C.P.D.; Bíró, T. Differential effectiveness of selected non-psychotropic phytocannabinoids on human sebocyte functions implicates their introduction in dry/seborrhoeic skin and acne treatment. Exp. Dermatol. 2016, 25, 701-707. [CrossRef] [PubMed]

106. ASX/Media Release BTX 1503 acne Phase 2 study results presentation; Philadelphia PA and Syndey Australia. 2019. Available online: https:/ / www.asx.com.au/asxpdf/20191023/pdf/449s36d2bz6vfr.pdf (accessed on 11 August 2021).

107. Petrosino, S.; Verde, R.; Vaia, M.; Allarà, M.; Iuvone, T.; Di Marzo, V. Anti-inflammatory Properties of Cannabidiol, a Nonpsychotropic Cannabinoid, in Experimental Allergic Contact Dermatitis. J. Pharmacol. Exp. Ther. 2018, 365, 652-663. [CrossRef] [PubMed]

108. Kozela, E.; Juknat, A.; Kaushansky, N.; Ben-Nun, A.; Coppola, G.; Vogel, Z. Cannabidiol, a non-psychoactive cannabinoid, leads to EGR2-dependent anergy in activated encephalitogenic T cells. J. Neuroinflammation 2015, 12, 52. [CrossRef] [PubMed]

109. Gaffal, E.; Cron, M.; Glodde, N.; Tüting, T. Anti-inflammatory activity of topical THC in DNFB-mediated mouse allergic contact dermatitis independent of CB1 and CB2 receptors. Allergy 2013, 68, 994-1000. [CrossRef]

110. Maor, Y.; Yu, J.; Kuzontkoski, P.M.; Dezube, B.J.; Zhang, X.; Groopman, J.E. Cannabidiol Inhibits Growth and Induces Programmed Cell Death in Kaposi Sarcoma-Associated Herpesvirus-Infected Endothelium. Genes Cancer 2012, 3, 512-520. [CrossRef]

111. Armstrong, J.; Hill, D.S.; McKee, C.S.; Hernandez-Tiedra, S.; Lorente, M.; Lopez-Valero, I.; Anagnostou, M.E.; Babatunde, F.; Corazzari, M.; Redfern, C.; et al. Exploiting Cannabinoid-Induced Cytotoxic Autophagy to Drive Melanoma Cell Death. J. Investig. Dermatol. 2015, 135, 1629-1637. [CrossRef]

112. Glodde, N.; Jakobs, M.; Bald, T.; Tüting, T.; Gaffal, E. Differential role of cannabinoids in the pathogenesis of skin cancer. Life Sci. 2015, 138, 35-40. [CrossRef] [PubMed]

113. Simmerman, E.; Qin, X.; Yu, J.C.; Baban, B. Cannabinoids as a Potential New and Novel Treatment for Melanoma: A Pilot Study in a Murine Model. J. Surg. Res. 2019, 235, 210-215. [CrossRef]

114. Wilkinson, J.D.; Williamson, E. Cannabinoids inhibit human keratinocyte proliferation through a non-CB1/CB2 mechanism and have a potential therapeutic value in the treatment of psoriasis. J. Dermatol. Sci. 2007, 45, 87-92. [CrossRef]

115. Changoer, L.; Anastassov, G. METHOD TO TREAT PSORIASIS 2019. Available online: https://patentscope.wipo.int/search/en/ detail.jsf?docId=US238100786\&docAn=16106420 (accessed on 11 August 2021).

116. Muscarà, C.; Smeriglio, A.; Trombetta, D.; Mandalari, G.; La Camera, E.; Occhiuto, C.; Grassi, G.; Circosta, C. Antioxidant and antimicrobial activity of two standardized extracts from a new Chinese accession of non-psychotropic Cannabis sativa L. Phytotherapy Res. 2020, 35, 1099-1112. [CrossRef]

117. Casares, L.; García, V.; Garrido-Rodriguez, M.; Millán, E.; Collado, J.A.; García-Martín, A.; Peñarando, J.; Calzado, M.A.; de la Vega, L.; Muñoz, E. Cannabidiol induces antioxidant pathways in keratinocytes by targeting BACH1. Redox Biol. 2020, $28,101321$. [CrossRef] [PubMed] 
118. Zagórska-Dziok, M.; Bujak, T.; Ziemlewska, A.; Nizioł-Łukaszewska, Z. Positive Effect of Cannabis sativa L. Herb Extracts on Skin Cells and Assessment of Cannabinoid-Based Hydrogels Properties. Molecules 2021, 26, 802. [CrossRef] [PubMed]

119. Appendino, G.; Gibbons, S.; Giana, A.; Pagani, A.; Grassi, G.; Stavri, M.; Smith, E.; Rahman, M. Antibacterial Cannabinoids from Cannabis sativa: A Structure-Activity Study. J. Nat. Prod. 2008, 71, 1427-1430. [CrossRef]

120. Wardle, J. Linking Chemical Phenotypes of Different Varieties of Cannabis Sativa to Their Antimicrobial Activities against a Range of Microorganisms. Master's Thesis, Manchester Metropolitan University, Manchester, UK, September 2019.

121. Turner, C.E.; ElSohly, M.A. Biological Activity of Cannabichromene, its Homologs and Isomers. J. Clin. Pharmacol. 1981, 21, 283S-291S. [CrossRef] [PubMed]

122. Karas, J.A.; Wong, L.J.M.; Paulin, O.K.A.; Mazeh, A.C.; Hussein, M.H.; Li, J.; Velkov, T. The Antimicrobial Activity of Cannabinoids. Antibiotics 2020, 9, 406. [CrossRef] [PubMed]

123. Vacek, J.; Vostalova, J.; Papouskova, B.; Skarupova, D.; Kos, M.; Kabelac, M.; Storch, J. Antioxidant function of phytocannabinoids: Molecular basis of their stability and cytoprotective properties under UV-irradiation. Free. Radic. Biol. Med. 2021, 164, 258-270. [CrossRef]

124. Millar, S.A.; Maguire, R.F.; Yates, A.S.; O'Sullivan, S.E. Towards Better Delivery of Cannabidiol (CBD). Pharmaceuticals 2020, 13, 219. [CrossRef]

125. Bruni, N.; Della Pepa, C.; Oliaro-Bosso, S.; Pessione, E.; Gastaldi, D.; Dosio, F. Cannabinoid Delivery Systems for Pain and Inflammation Treatment. Molecules 2018, 23, 2478. [CrossRef]

126. Casiraghi, A.; Musazzi, U.M.; Centin, G.; Franzè, S.; Minghetti, P. Topical Administration of Cannabidiol: Influence of VehicleRelated Aspects on Skin Permeation Process. Pharmaceuticals 2020, 13, 337. [CrossRef]

127. Ali, A.; Akhtar, N. The safety and efficacy of 3\% Cannabis seeds extract cream for reduction of human cheek skin sebum and erythema content. Pak. J. Pharm. Sci. 2015, 28, 1389-1395.

128. Adusumilli, N.C.; Hazuka, E.L.; Friedman, A.J. Nanotechnology to deliver cannabinoids in dermatology. Precis. Nanomed. 2021, 4, 787-794. [CrossRef]

129. Da Porto, C.; Decorti, D.; Tubaro, F. Fatty acid composition and oxidation stability of hemp (Cannabis sativa L.) seed oil extracted by supercritical carbon dioxide. Ind. Crop. Prod. 2012, 36, 401-404. [CrossRef]

130. Uluata, S.; Özdemir, N. Antioxidant Activities and Oxidative Stabilities of Some Unconventional Oilseeds. J. Am. Oil Chem. Soc. 2012, 89, 551-559. [CrossRef]

131. Dąbrowski, G.; Skrajda, M. Frakcja Lipidowa I Białkowa Nasion Konopi Siewnych (C. sativa L.) Oraz Jej Korzystny Wpływ Na Zdrowie Człowieka = Lipid and Protein Fraction of Hemp Seed (C. sativa L.) And Its Beneficial Influence On Human Health. J. Educ. Health Sport. 2016, 6, 357-366. [CrossRef]

132. Kazlauskienè, D.; Kasparavičienè, G.; Nenortienè, P.; Marksa, M.; Jukilaitytė, J.; Velžienè, S.; Ževžikovas, A. Determination of fatty acid composition and antioxidant activity in vegetable oils. Chemija 2021, 32. [CrossRef]

133. Balić, A.; Vlašić, D.; Žužul, K.; Marinović, B.; Mokos, Z.B. Omega-3 Versus Omega-6 Polyunsaturated Fatty Acids in the Prevention and Treatment of Inflammatory Skin Diseases. Int. J. Mol. Sci. 2020, 21, 741. [CrossRef] [PubMed]

134. Moore, E.M.; Wagner, C.; Komarnytsky, S. The Enigma of Bioactivity and Toxicity of Botanical Oils for Skin Care. Front. Pharmacol. 2020, 11. [CrossRef]

135. Wydro, D.M. Omega-3 and 6 Acids in Medicine and Cosmetology. The Effect of Oral Supplementation with Omega-3 and 6 Acids on Skin Condition-Pilot Study. Available online: https://www.researchgate.net/publication/270960751_Kwasy_omega_ 3_i_6_w_medycynie_i_kosmetologii_Wplyw_doustnej_suplementacji_kwasami_omega-3_i_6_na_kondycje_skory_-_badanie_ pilotazowe_Omega-3_and_6_acids_in_medicine_and_cosmetology_The_effect_of_oral_(accessed on 15 June 2021).

136. Pei, L.; Luo, Y.; Gu, X.; Wang, J. Formation, Stability and Properties of Hemp Seed Oil Emulsions for Application in the Cosmetics Industry. Tenside Surfactants Deterg. 2020, 57, 451-459. [CrossRef]

137. Kurek-górecka, A.; Balwierz, R.; Mizera, P.; Nowak, M.; Żurawska-płaksej, E. L'importance thérapeutique et cosmétique de 1 ' huile de chanvre. BioResources 2018, 16, 704-708.

138. Metwally, S.; Ura, D.P.; Krysiak, Z.J.; Kaniuk, Ł.; Szewczyk, P.K.; Stachewicz, U. Electrospun PCL Patches with Controlled Fiber Morphology and Mechanical Performance for Skin Moisturization via Long-Term Release of Hemp Oil for Atopic Dermatitis. Membranes 2021, 11, 26. [CrossRef]

139. Nowak, I.; Zielińska, A.K. tłuszczowe w olejach roślinnych i ich znaczenie w kosmetyce. Chemik 2014, 68, 103-110.

140. Simopoulos, A. The importance of the ratio of omega-6/omega-3 essential fatty acids. Biomed. Pharmacother. 2002, 56, 365-379. [CrossRef]

141. Cunliffe, W.J.; Holland, D.; Jeremy, A. Comedone formation: Etiology, clinical presentation, and treatment. Clin. Dermatol. 2004, 22, 367-374. [CrossRef] [PubMed]

142. Callaway, J.; Schwab, U.; Harvima, I.; Halonen, P.; Mykkänen, O.; Hyvönen, P.; Järvinen, T. Efficacy of dietary hempseed oil in patients with atopic dermatitis. J. Dermatol. Treat. 2005, 16, 87-94. [CrossRef] [PubMed]

143. Liang, J.; Aachary, A.A.; Thiyam-Holländer, U. Hemp Seed Oil: Minor components and oil quality. Lipid Technol. 2015, 27, 231-233. [CrossRef]

144. Wisniewska, A.; Widomska, J.; Subczynski, W.K. Carotenoid-membrane interactions in liposomes: Effect of dipolar, monopolar, and nonpolar carotenoids. Acta Biochim. Pol. 2006, 53, 475-484. [CrossRef] 
145. Baswan, S.M.; Klosner, A.E.; Weir, C.; Salter-Venzon, D.; Gellenbeck, K.W.; Leveret, J.; Krutmann, J. Role of Ingestible Carotenoids in Skin Protection: A Review of Clinical Evidence. Photodermatol. Photoimmunol. Photomed. 2021. [CrossRef]

146. Hajizadeh-Sharafabad, F.; Zahabi, E.S.; Malekahmadi, M.; Zarrin, R.; Alizadeh, M. Carotenoids supplementation and inflammation: A systematic review and meta-analysis of randomized clinical trials. Crit. Rev. Food Sci. Nutr. 2021, 1-17. [CrossRef]

147. Atalay, S.; Jarocka-Karpowicz, I.; Skrzydlewska, E. Antioxidative and Anti-Inflammatory Properties of Cannabidiol. Antioxidants 2019, 9, 21. [CrossRef]

148. Quirin, K. Phytosterol-Rich Soy Germ and Guggul Extracts Provide Anti-Ageing Benefits. Cosmet. Sci. Technol. $2011,8,18-27$.

149. Smith, L.W. The Present Status of topical Chlorophyll Therapy. NY State J. Med. 1995, 14, 2041-2050.

150. Stephens, T.J.; McCook, J.P.; Herndon, J.H. Pilot Study of Topical Copper Chlorophyllin Complex in Subjects With Facial Acne and Large Pores. J. Drugs Dermatol. 2015, 14, 589-592. [PubMed]

151. McCook, J.P.; Stephens, T.J.; Jiang, L.I.; Law, R.M.; Gotz, V. Ability of sodium copper chlorophyllin complex to repair photoaged skin by stimulation of biomarkers in human extracellular matrix. Clin. Cosmet. Investig. Dermatol. 2016, 9, 167-174. [CrossRef] [PubMed]

152. Ferreira, V.D.S.; Sant'Anna, C. Impact of culture conditions on the chlorophyll content of microalgae for biotechnological applications. World J. Microbiol. Biotechnol. 2017, 33, 20. [CrossRef] [PubMed]

153. O'sullivan, S.E. Marijuana and the Cannabinoids, 1st ed.; ElSohly, M.A., Ed.; Humana Press: Totowa, NJ, USA, 2007; ISBN 978-1-58829-456-2.

154. McPartland, J.M.; Russo, E.B. Cannabis and Cannabis Extracts: Greater than The Sum of Their Parts. In Cannabis Therapeutics in HIV/AIDS; Taylor and Francis Inc.: Abingdon, UK, 2012; pp. 103-132. ISBN 9780203049105.

155. Barrett, M.; Gordon, D.; Evans, F. Isolation from Cannabis sativa L. of cannflavin-A novel inhibitor of prostaglandin production. Biochem. Pharmacol. 1985, 34, 2019-2024. [CrossRef]

156. Erridge, S.; Mangal, N.; Salazar, O.; Pacchetti, B.; Sodergren, M.H. Cannflavins-From plant to patient: A scoping review. Fitoterapia 2020, 146, 104712. [CrossRef] [PubMed]

157. Calvi, L.; Pentimalli, D.; Panseri, S.; Giupponi, L.; Gelmini, F.; Beretta, G.; Vitali, D.; Bruno, M.; Zilio, E.; Pavlovic, R.; et al. Comprehensive quality evaluation of medical Cannabis sativa L. inflorescence and macerated oils based on HS-SPME coupled to GC-MS and LC-HRMS (q-exactive orbitrap ${ }^{\circledR}$ ) approach. J. Pharm. Biomed. Anal. 2018, 150, 208-219. [CrossRef] [PubMed]

158. Pavlovic, R.; Nenna, G.; Calvi, L.; Panseri, S.; Borgonovo, G.; Giupponi, L.; Cannazza, G.; Giorgi, A. Quality Traits of “Cannabidiol Oils": Cannabinoids Content, Terpene Fingerprint and Oxidation Stability of European Commercially Available Preparations. Molecules 2018, 23, 1230. [CrossRef] [PubMed]

159. Wakshlag, J.J.; Cital, S.; Eaton, S.J.; Prussin, R.; Hudalla, C. Cannabinoid, Terpene, and Heavy Metal Analysis of 29 Over-theCounter Commercial Veterinary Hemp Supplements. Veter-Med. Res. Rep. 2020, 11, 45-55. [CrossRef]

160. Leizer, C.; Ribnicky, D.; Poulev, A.; Dushenkov, S.; Raskin, I. The Composition of Hemp Seed Oil and Its Potential as an Important Source of Nutrition. J. Nutraceuticals Funct. Med. Foods 2000, 2, 35-53. [CrossRef]

161. Hanuš, L.O.; Hod, Y. Terpenes/Terpenoids in Cannabis: Are They Important? Med. Cannabis Cannabinoids 2020, 3, 25-60. [CrossRef]

162. Anand, U.; Pacchetti, B.; Anand, P.; Sodergren, M.H. Cannabis-based medicines and pain: A review of potential synergistic and entourage effects. Pain Manag. 2021, 11, 395-403. [CrossRef] [PubMed]

163. Ben-Shabat, S.; Fride, E.; Sheskin, T.; Tamiri, T.; Rhee, M.H.; Vogel, Z.; Bisogno, T.; De Petrocellis, L.; Di Marzo, V.; Mechoulam, R. An entourage effect: Inactive endogenous fatty acid glycerol esters enhance 2-arachidonoyl-glycerol cannabinoid activity. Eur. J. Pharmacol. 1998, 353, 23-31. [CrossRef]

164. Wagner, H.; Ulrich-Merzenich, G. Synergy research: Approaching a new generation of phytopharmaceuticals. Phytomedicine 2009, 16, 97-110. [CrossRef] [PubMed]

165. Cogan, P.S. The 'entourage effect' or 'hodge-podge hashish': The questionable rebranding, marketing, and expectations of cannabis polypharmacy. Expert Rev. Clin. Pharmacol. 2020, 13, 835-845. [CrossRef]

166. Russo, E.B. Taming THC: Potential cannabis synergy and phytocannabinoid-terpenoid entourage effects. Br. J. Pharmacol. 2011, 163, 1344-1364. [CrossRef] [PubMed] 